\title{
Information Technology in Health Care: Information Retrieval, Processing, and Protection (Review)
}

\author{
DOI: $10.17691 / \mathrm{stm} 2018.10 .3 .26$
}

Received October 22, 2017

A.B. Kuznetsov, MD, PhD, Assistant, Department of Anesthesiology and Resuscitation;

A.S. Mukhin, MD, DSc, Professor, Head of the Department of Surgery;

I.S. Simutis, MD, PhD, Assistant, Department of Anesthesiology and Resuscitation;

L.A. Shchegolkov, MD, PhD, Assistant, Department of Anesthesiology and Resuscitation;

G.A. Boyarinov, MD, DSc, Professor, Head of the Department of Anesthesiology and Resuscitation

Privolzhsky Research Medical University, 10/1 Minin and Pozharsky Square, Nizhny Novgorod, 603005, Russia

Hacker attacks on information resources in clinics of the UK, Belgium, Lithuania, clinical and biochemical laboratories in Russia and Belarus in 2017 as well as the refusal of 199 German hospital managers to use modern computer information technologies in 2016 gave an impetus to investigate the issue of computerization in health-care facilities.

The need for using computer information technology is unchallengeable, though its current use in clinical practice is associated with a number of problems. Besides, the amount of clinical data is increasing, while some information remains unanalyzed posing risks of fatal errors.

This review describes the problems of computer technology implementation, use, and protection. To make computer technology work effectively in the health care system, we have to deal with the following problems: architecture compatibility, perception and interpretation of handwritten text, interpretation of medical terms, text formalization and standardization, creation of electronic medical notes, development of electronic medical records and databases, personalization and protection of information.

Key words: information technologies in medicine; computer technologies in health care; data protection.

\section{Introduction}

Development of high medical technology leads to an increase in the flow of digital information in health-care facilities, however, some data are not analyzed, which may cause fatal consequences [1, 2].

In computer science, the human body is a complex hierarchical self-regulating system, while critical situations are considered as a simultaneous action of many factors with possible effect, which is difficult to describe mathematically [3-9].

The need for using computer information technology is beyond argument. For example, today, $88 \%$ of medical workers use smartphones to communicate with each other, receive orders, interpret laboratory tests and perform mathematical calculations [10-13]. However, the wide use of computer technology is difficult due to a large number of emerging problems [14-34].

The problem of architecture compatibility. The computer hardware platform (architecture) includes software controlling the processor core and a set of commands. Hardware platforms differ in components and software. Dissonance in the operation of hardware platforms is caused by differences in codes, processors, capacity, motherboards, programming languages, software. Coordination of software functions on more than one hardware platform is no easy matter, a task that remains unsolved. The same software developer often provides many incompatible software products for different operating systems, 32-bit and 64-bit versions are found within one operating system. To solve compatibility problems, auxiliary programs serving as bridges should be created, their developer must understand clearly the capabilities of existing and new equipment whose complete characteristics are often withheld by the manufacturer. The time for creating bridge programs is equal to or exceeds the time of acquiring up-to-date equipment. As a result, the problem is cycled $[22,35]$.

The problem of text perception and interpretation by the computer. The array of medical information is usually stored on paper. Its replacement with electronic copies is blocked by differences in computer infrastructure development in each individual healthcare facility, unequal distribution of computer knowledge among employees, administrative deterrence.

In natural speech, a word or phrase can have more than one meaning $[30,36]$. In context, they are easily

Corresponding author: Aleksandr B. Kuznetsov, e-mail: albor1954@yandex.ru 
understood by man; in a number of cultures (China, Japan, Mongolia), the context is one of the main features of speech. For a computer, this situation is unacceptable, therefore misunderstanding begins at the stage of computer perception of the text. Automated methods of natural language processing are still complicated structurally, ineffective and compatible only with standardized electronic medical records at best [37]. Computer software requires bloated deductive "interpreting" applications often exceeding the main program in volume.

Exact interpretation of synonyms, homonyms, abbreviations, neologisms is a difficult task as correct text interpretation depends on the meaning chosen by the computer program [38-42]. Many medical terms are also ambiguous and a computer program cannot automatically identify most of them [43-46]. Blank text fields, doctor's handwriting, unusual word combinations, and expressions aggravate the problem. Even readable medical texts cannot be subjected to automatic processing, it is necessary to adapt them manually, which takes time and requires trained professionals [47-50].

The problem of text formalization. Formalization (archetypization) is a very time-consuming manual process because it is impossible to automate exact data transfer to a computer program [51]. For example, a computer program is unable to understand that Russian word "образование" has different meanings depending on the context: physical meaning (formation of an electron), pedagogical one (education). Besides, it takes no account of the subtext or the previous text to solve the current problem when an ambiguous expression

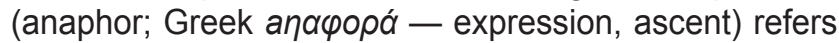
to an earlier statement (antecedent; Latin antecedens previous). Anaphoric-antecedent combinations are poorly compatible with computer languages, require special semantic (Greek semantikos - meaning) bridge programs, rigid fixation of co-referential anaphoricantecedent combinations [52]. To formalize medical expressions, it is necessary to create a new professional language for medical workers that would be fully understood by computer programs.

The Unified Medical Language System (UMLS) developed by the National Medical Library of the USA is structurally complex, cumbersome and problematic in practical use [53].

The problem of text standardization. Standardization of natural language concepts is another unsolved problem [54-56]. For example, adoption of unified international terminology standards is complicated because of language differences. Even standardization in conventional paper form is hardly a common practice. Wijdiks [57] found that $70(88 \%)$ of 80 countries have recommendations for determining brain death, and 55 (69\%) have standards for organ transplantation.

For accurate interpretation of fragmented (part/ whole) data, a computer program has to establish many relationships between parts of the whole and to have extensive knowledge in a particular subject area [58, 59]. The computer copes successfully with structured tabulated data (order forms of drugs, arrays of laboratory indices). However, unstructured textual data processing in different natural languages is impossible without numerous and often incompatible bridge programs which are more complex than the main program [60].

Standardization problem is complicated by the fact that groups of scientists create a specialized language making their communication in a restricted team easier. This creates barriers not only for computer programs but also for colleagues, even if they work in the same organization [61].

The problem of creating electronic medical notes. Existing methods of automated text processing are unable to make notes understandable for a computer program [25, 62]. However, formalized standardized notes are the basis of an electronic medical record [63] Development of programs for automated processing of electronic medical notes as well as small administrative, laboratory, clinical databases can significantly simplify diagnostic and treatment processes, but creation of such products is extremely expensive time-consuming task [64-67].

Computer technologies have revolutionized medical imaging (table, graph, picture), solved problems of creating, obtaining, archiving, storing and exchanging high-quality scan images, increased the importance of electronic medical notes [68, 69]. However, about $80 \%$ of the information cannot be processed automatically because it is stored in an unstructured form [70].

The problem of creating electronic medical records. The electronic medical record (electronic medical history) is intended to become an important part of global medical information electronic databases [71, 72]. Today, it is information software [73-80] limiting medical processes to a rigid framework necessary for data processing. However, the human body as the most perfect and rapidly changing biological system does not fit into the strict boundaries of that framework. Visual data analytics can be a solution [81].

Creation of electronic medical records is unthinkable without wide dissemination of systems for registration, storage and presentation of patient information as well as drug provision [82-91]. Besides, standardization of concepts and terminology is required for their effective use [92].

The problem of creating electronic databases. The electronic database is a network system for storage, analysis, and management of large volumes of heterogeneous data in a single format [93]. Centralized medical databases include electronic patient records and local information systems [94, 95]. Database effectiveness shows itself even in simple ordering of indices, normalization of distribution increases sensitivity from 48.3 to $92.0 \%$, specificity from 70.5 
to $99.8 \%$ [96-98]. It is important to build databases simultaneously with new method implementation as in Food and Drug Administration (FDA) when using a surgical laser: messages - 21, of them 7 were about the fatal outcome [99].

Centralized databases require powerful and expensive search engines as data comes from information systems in different formats and may have differences in schema and encoding making it difficult to recognize the content of a certain source. Often only abstracts of articles are processed, which makes it almost impossible to exchange and integrate data [68, 100-102].

The problem of using computer technology. Untimely recognized and corrected problems in the work of equipment in operating rooms and intensive care units may affect health care quality and lead to disability or death [103-105]. The situation is aggravated by the fact that doctors admitted to independent work are sometimes poorly trained to use high-tech equipment, they often acquire practical skills on patients putting their health and life at risk [106-108]. Moreover, medical staff of operating rooms and intensive care units often receive a large number of fragmentary, contradictory, unsystematic and sometimes untimely data. In conditions of acute time shortage, all of this complicates analysis and correct interpretation [1, 109-113]. Attempts to clarify the information may be left without response as the computer program does not always understand requests addressed to it [114]. Nevertheless, computer technology deployment has greatly facilitated diagnosis and treatment of patients.

For example, computed tomography with automated quantitative analysis of the cranial vault, suture, and intracranial volume asymmetry parameters increased the average accuracy of diagnosing neurological and neurosurgical diseases from 86.9 to $91.9 \%$ [115]. Computer consulting system gives the surgeon correct leads as to the necessity of using neurophysiological, ultrasound and neuronavigation equipment in $90-95 \%$ of cases [116]. At the same time, the computer system for semi-automated ultrasound examination of carotid artery bifurcation stenosis requires a thorough analysis of its effectiveness [117].

A computer system is being developed for obtaining and storing information, extracting knowledge from databases, predicting the risk of adverse outcomes with elements of training the system based on neural networks by analogy with natural neurogenesis, apoptosis, neuroplasticity [118, 119].

Personalization problem. Events with non-fixed status underlie functional impairment of vital organs/ systems. For example, coagulogram indices may indicate a hypocoagulation phase of disseminated intravascular coagulation syndrome in a particular patient, while there are no signs of internal bleeding, blood-soaked bandages or hemorrhagic manifestations on the skin and mucous membranes [120].
This situation puts the doctor in a difficult situation because treatment standards are regulated by quantitative indices. In view of this, personalized medicine that studies the individual response to the disease or pathological condition is becoming more and more important. With this approach, each diagnostic and/or therapeutic action is strictly personalized for the patient [31, 121-124]. Attempts are made to use mathematical methods for calculating the risk of complications, drug administration/withdrawal when correcting the functions of vital organs/systems such as the heart, liver, immune system [26].

Mathematical analysis and computer modeling prove to be effective in predicting treatment results when biological parameters are rigidly connected with the laws of physics and mathematics: for example, when calculating the biophysical parameters of multifocal implantable ocular lenses (artificial eye lenses). In areas where there is no that rigid relationship (critical conditions, multiple organ failure), the problem of predicting treatment outcomes remains unsolved [125-127].

The problem of data protection. Centralized databases prefer to store information in "cloud" storage on a remote server, though it is unsafe. Nobody guarantees that server service employees do not exceed their official authority and do not want to access the stored information [21, 128-136]. Even protection is useless in this case: 1) password protection: a complex password; 2) attribute: a magnetic card, a smart card, an intelligent token for USB access; 3) biometric protection: identification by physical or behavioral traits of a person [15-17].

Stationary, mobile, and especially implantable medical electronic devices (lung ventilators, cardiac pumps, defibrillators, pacemakers, perfusors, infusion pumps, biosensors, neurostimulators) [21, 24] for supporting or replacing vital functions of organs/systems are exposed to danger of hacking, unauthorized changes in parameters, as well as complete remote shutdown by intruders, which makes their use unsafe. In this regard, creation of software to protect such devices is one of the most important challenges in the development of high medical technologies.

The problem of information technology effectiveness. At present, practical use of modern computer resources is hardly effective [137]. Attempts to standardize terminology even in the simplest professional language of nurses are uncoordinated, research is duplicated and knowledge base requires updating [138].

The widespread belief that electronic medical records improve diagnostic and therapeutic measures has proved inappropriate in situations where it is necessary to act in a rigid time-frame: emergency care, surgery, anesthesiology, resuscitation [29]. The value of electronic medical records is somewhat exaggerated, since most of the data is presented in a free text 
format and cannot be used for analysis, algorithm development, creation of clinical decision support systems [27].

In this regard, the ever-growing volume of information in databases can only potentially improve medical care. To process incoming information of various types and structure, high-performance computer programs running only on a very powerful and expensive computer operating system are required [139].

Most of the known databases are lists of terms in a hierarchical sequence of coded indices designed to solve a single task. For example, computer programs using source codes automatically identify one-component dosage forms in $62.5 \%$, while multicomponent ones only in $7.5 \%$ of cases. The problem of centralized databases is clinical terminology differences in various medical databases [140]. It is impossible to find all the available information in a centralized database at user request, about $90 \%$ is estimated as a good result, however, the information obtained may be false or outdated, since the source of information is not recorded $[68,141]$. The accuracy of text interpretation even in standardized medical records in databases is insignificant: it is 0.897 for subject "test", 0.852 — "face", 0.855 — "problem", 0.884 - "treatment" [25].

The increase in the number of users who simultaneously access the system leads to the increase in the time of response to the request. Fast reliable response is possible under the load less than 0.5 resource power [142].

Free domestic web service with OnDoc mobile application created without participation of medical specialists offers the patient personal health analytics, identification of possible risks, recommends ways to eliminate them.

After signing-up on the site, an electronic device equal to a smartphone in class is used to enter the following data: age, height, weight, blood group, blood pressure of comfort, heart rate, visual acuity, blood sugar level, cholesterol level, temperature, allergies, surgeries, habits, lifestyle, prescribed medications, doctor recommendations. The patient receives reminders about follow-up visits, additional recommendations, test results, extracts from electronic medical records. Based on recognition (digitization) of documents and information entered, the application creates an electronic medical record that is stored on the patient's personal device. Development of new modules expands the capabilities of OnDoc service, but the application no longer fits in a regular smartphone requiring new expensive devices [18].

The use of new expensive diagnostic medical equipment is unreasonable in many cases. Computerization has increased the cost of cancer treatment in the United States by $72 \%$ over the past ten years without remarkable improvement in treatment outcomes, which compromises health system ability to provide quality cancer care using computer technology
$[22,32]$. The use of 3D technology for modeling the planned surgical treatment is limited due to high cost of equipment and lack of specialists [14]. For example, managers of 199 German hospitals abandoned three-dimensional multi-level computer model of clinical information logistics in favor of less complex conservative methods [28, 32].

Complex studies involving physicists, chemists, mathematicians, engineers, biologists are required for mathematical representation of complex biological processes and minimization of clinical tests. Long-term systematic search for simple, convenient, universal software with a set of functions ranging from knowledge extraction to decision-making leads to no success [32, 143]. Existing computer systems for risk assessment fail to record $50-96 \%$ of critical situations [99]. The state of medical information technology looks like information chaos when it comes to the analysis of events with non-fixed status, such as critical conditions, multiple organ failure $[19,33]$. A simple formula is relevant in these conditions: fatal outcome probability $\operatorname{FOP}(\%)=25 D F+2 A+1 C$, where $D F$ is the number of vital organs/systems with decompensated failure (severe dysfunction) and/or lack of functions, $A$ is the number of acute diseases and/or exacerbations of chronic diseases, $C$ is the number of chronic diseases $[9,144]$.

\section{Conclusion}

Computer information technologies can both simplify and improve the quality of medical care, but their effectiveness is quite low today. Therefore, search for simple, fact-based ways to predict treatment outcomes in real time remains an urgent task of health care today.

Study funding and conflict of interests. This study was not supported by any financial sources and the authors have no conflict of interests to disclose.

\section{References}

1. Ng K., Ghoting A., Steinhubl S.R., Stewart W.F., Malin B., Sun J. PARAMO: a PARAllel predictive MOdeling platform for healthcare analytic research using electronic health records. J Biomed Inform 2014; 48: 160-170, https:// doi.org/10.1016/j.jbi.2013.12.012.

2. Pai V.M., Rodgers M., Conroy R., Luo J., Zhou R., Seto B. Workshop on using natural language processing applications for enhancing clinical decision making: an executive summary. J Am Med Inform Assoc 2014; 21(e1): e2e5, https://doi.org/10.1136/amiajnl-2013-001896.

3. Ilyasov R.R., Kalinchenko S.Yu., Danilov A.B. The role of sex hormones in the perception of pain. Manage Pain 2015; 2: 4-9.

4. Kraus O. Possibilities and methods of therapy of diseases of phases of impregnation and degeneration. $B M$ : Biologicheskaya meditsina 2015; 2: 6-12. 
5. Smit A. Introduction to bioregulatory medicine: theoretical and practical aspects. BM: Biologicheskaya meditsina 2015; 2: 17-29.

6. Boyarinov G.A., Deryugina A.V., Boyarinova L.V., Solovieva O.D., Zaitsev R.R., Moshnina E.V., Voennov O.V., Shumilova A.V. Experimental grounding and results of applying Mexicor for correction of proand antioxidant system disorders in the case of patients having complex thoracoabdominal trauma. Medial 2015; 16(2): 31-35.

7. Holmes J.H. Methods and applications of evolutionary computation in biomedicine. J Biomed Inform 2014; 49: 11-15, https://doi.org/10.1016/j.jbi.2014.05.008.

8. Hoverman J.R. From the first visit on: information technology and communication. J Oncol Practice 2013; 9(3): 152-154, https://doi.org/10.1200/jop.2013.000974.

9. Kuznetsov A.B. Prognozirovanie rezultatov lecheniya patsienta $v$ kriticheskom sostoyanii [Predicting the results of treatment of a patient in a critical condition]. Saarbrücken: LAP LAMBERT Academic Publishing; 2015; 248 p.

10. Dilenyan L.R., Bagry A.S., Belkaniya G.S., Ryzhakov D.I., Pukhalskaya L.G. Anthropogenetic and ontogenetic model of general clinical evidence of somatic human condition. Medicinskij al'manah 2015; 4(39): 222-227.

11. Gumanenko E.K., Rud' A.A., Khromov A.A., Chapurin V.A. Znachenie obektivnoy otsenki tyazhesti sostoyaniya postradavshikh $\mathrm{v}$ diagnostike poliorgannoy disfunktsii i infektsionnykh oslozhneniy tyazhelykh travm. V kn.: Peritonit ot A do Ya (Vserossiyskaya shkola) [The significance of an objective assessment of the severity of the condition of the victims in the diagnosis of multiple organ dysfunction and infectious complications of severe injuries. In: Peritonitis from A to Z (All-Russian School)]. Pod red. Laricheva A.B. [Larichev A.B. (editor)]. Yaroslavl; 2016; p. 212-217.

12. Kuznetsov A.S., Polyanskiy A.A., Volynskiy P.V., Efremov R.G. Kompyuternoe modelirovanie dimerizatsii transmembrannykh domenov glikoforina A: dominiruyushchaya rol effektov sredy. $\mathrm{V}$ kn.: Materialy $V$ sezda biofizikov Rossii. T. 1 [Computer simulation of dimerization of glycophorin A transmembrane domains: the dominant role of medium effects. In: Materials of the 5th Congress of Russian Biophysicists. Vol. 1]. Pod red. Rubina A.B., Uzdenskogo A.B. [Rubin A.B., Uzdenskiy A.B. (editors)]. Rostov-on-Don: Izdatelstvo Yuzhnogo federalnogo universiteta; 2015; p. 92.

13. Anshari M., Almunavar M.N. Modile healt (mHealt) services and online educators. Biomed Inform Insights 2016; 8: 19-27, https://doi.org/10.4137/bii.s35388.

14. Filippova A.V., Baindurashvili A.G., Komosko M.M., Semenov M.G., Zaripova Z.A. Using 3D technologies in medicine. Virtualnye tekhnologii $v$ meditsine 2015; 14(2): 38-39.

15. Kazantsev I.S., Kudryakov S.D., Shitikov A.S. Implementation mechanisms of permanent stealth keyboard monitoring subsystem for detecting legitimate operator substitution. Sovremennye tendentsii razvitiya nauki $i$ tekhnologiy 2016; 5-3: 61-63.

16. Kazantsev I.S. Methods of operator identification and authentication in modern systems of information access control and management. Sovremennye tendentsii razvitiya nauki $i$ tekhnologiy 2016; 5-3: 63-66.

17. Kolomoitcev V.S. Choice of option for implementation of the multilevel secure access to the external network.
Nauchno-tehnicheskii vestnik informatsionnykh tekhnologii, mekhaniki i optik 2016; 16(1): 115-121, https://doi. org/10.17586/2226-1494-2016-16-1-115-121.

18. ONDOC. URL: http://www.ondoc.me.

19. Kucherova V.Yu., Petkov V.N., Artamonov P.A Foundation of ADAR method in the solution of a problem for typical nonlinear systems balanced modes stabilization. Fundamentalnye issledovaniya 2016; 5-2: 264-268.

20. Akimov V.P., Batalov I.Kh., Tvorogov D.A., Zenkova A.V. Posleoperatsionnyy zhelchnyy peritonit. V kn.: Peritonit ot $A$ do Ya (Vserossiyskaya shkola) [Postoperative bile peritonitis. In: Peritonitis from $A$ to $Z$ (All-Russian School)]. Pod red. Laricheva A.B. [Larichev A.B. (editor)]. Yaroslavl; 2016; p. 66-67.

21. Jones K.H., Ford D.V., Jones C., Dsilva R., Thompson S., Brooks C.J., Heaven M.L., Thayer D.S., McNerney C.L., Lyons R.A. A case study of the Secure Anonymous Information Linkage (SAIL) Gateway: a privacyprotecting remote access system for health-related research and evaluation. J Biomed Inform 2014; 50: 196-204, https:// doi.org/10.1016/j.jbi.2014.01.003.

22. Schnipper L.E., Davidson N.E., Wollins D.S., Tyne C., Blayney D.W., Blum D., Dicker A.P., Ganz P.A., Hoverman J.R., Langdon R., Lyman G.H., Meropol N.J., Mulvey T., Newcomer L., Peppercorn J., Polite B., Raghavan D., Rossi G., Saltz L., Schrag D., Smith T.J., Yu P.P., Hudis C.A., Schilsky R.L.; American Society of Clinical Oncology. American Society of Clinical Oncology Statement: a conceptual framework to assess the value of cancer treatment options. J Clin Oncol 2015; 33(23): 2563-2557, https://doi.org/10.1200/ jco.2015.61.6706.

23. Beber M.E., Muskhelishvili G., Hütt M.T. Effect of database drift on network topology and enrichment analyses: a case study for RegulonDB. Database 2016; pii: baw003, https://doi.org/10.1093/database/baw003.

24. Camara C., Peris-Lopez P., Tapiador J.E. Security and privacy issues in implantable medical devices: a comprehensive survey. J Biomed Inform 2015; 55: 272-289, https://doi.org/10.1016/j.jbi.2015.04.007.

25. Chowdhury F.M., Zweigenbaum P. A controlled greedy supervised approach for co-reference resolution on clinical text. J Biomed Inform 2013; 46(3): 506-515, https://doi. org/10.1016/j.jbi.2013.03.007.

26. Clark M. Prediction of clinical risks by analysis of preclinical and clinical adverse events. J Biomed Inform 2015; 54: 167-173, https://doi.org/10.1016/j.jbi.2015.02.008.

27. Mehrabi S., Krishnan A., Sohn S., Roch A.M., Schmidt H., Kesterson J., Beesley C., Dexter P., Max Schmidt C., Liu H., Palakal M. DEEPEN: a negation detection system for clinical text incorporating dependency relation into NegEx. J Biomed Inform 2015; 54: 213-219, https://doi.org/10.1016/j.jbi.2015.02.010.

28. Thye J., Hübner U., Straede M.-C., Liebe J.-D. Development and evaluation of a three-dimensional multi-level model for visualising the workflow composite score in a health IT benchmark. J Biomed Eng Inform 2016; 2(2): 83-98, https:// doi.org/10.5430/jbei.v2n2p83.

29. Ben-Assuli O., Sagi D., Leshno M., Ironi A., Ziv A. Improving diagnostic accuracy using EHR in emergency departments: a simulation-based study. J Biomed Inform 2015; 55: 31-40, https://doi.org/10.1016/j.jbi.2015.03.004.

30. Ojo A.I., Popoola S.O. Some correlates of electronic health information management system success in Nigerian 
Teaching Hospitals. Biomed Inform Insights 2015; 7: 1-9, https://doi.org/10.4137/bii.s20229.

31. Miwa M., Thomas J., O'Mara-Eves A., Ananiadou S. Reducing systematic review workload through certainty-based Screening. J Biomed Inform 2014; 51: 242-253, https://doi. org/10.1016/j.jbi.2014.06.005.

32. Soares M., Salluh J.I. Providing high-quality and affordable intensive care to patients with cancer: the forgotten brick in the steep wall of costs throughout the cancer care continuum. J Clin Oncol 2014; 32(13): 1384-1385, https://doi. org/10.1200/jco.2013.54.6614.

33. Moran M.S., Kaufman C., Burgin C., Swain S., Granville T., Winchester D.P. What currently defines a breast center? Initial Data from the National Accreditation Program for breast centers. J Oncol Pract 2013; 9(9): e62-e70, https://doi. org/10.1200/jop.2012.000636.

34. Yu H., Zhang J.J., Lee T.-Y. Foldover-free shape deformation for biomedicine. J Biomed Inform 2014; 48: 137147, https://doi.org/10.1016/j.jbi.2013.12.011.

35. Ferrante A., Boyd J. A transparent and transportable methodology for evaluating Data Linkage software. J Biomed Inform 2012; 45: 165-172, https://doi.org/10.1016/j.jbi. 2011.10.006.

36. Sun W., Rumshisky A., Uzuner O. Temporal reasoning over clinical text: the state of the art. J Am Med Inform Assoc 2013; 20(5): 814-819, https://doi.org/10.1136/ amiajnl-2013-001760.

37. Cohen K.B., Glass B., Greiner H.M., Holland-Bouley K., Standridge S., Arya R., Faist R., Morita D., Mangano F., Connolly B., Glauser T., Pestian J. Methodological issues in predicting pediatric epilepsy surgery candidates through natural language processing and machine learning. Biomed Inform Insights 2016; 8: 11-18, https://doi.org/10.4137/bii. s38308.

38. Altabasova Z.Yu. Latest methods of neologism formation at the current stage of English language development. Sovremennye tendentsii razvitiya nauki $i$ tekhnologiy 2016; 5-4: 17-19.

39. Bykador V.S., Popov Yu.V. Parametric identification of high-order systems by regression methods using low-order models. Sovremennye tendentsii razvitiya nauki i tekhnologiy 2016; 5-3: 48-54.

40. Harispe S., Sanchez D., Ranwez S., Janaqi S., Montmain J. A framework for unifying ontology-based semantic similarity measures: a study in the biomedical domain. J Biomed Inform 2014; 48: 38-53, https://doi.org/10.1016/j. jbi.2013.11.006.

41. Bousquet C., Sadou E., Souvignet J., Jaulent M.-C., Declerck G. Formalizing MedDRA to support semantic reasoning on adverse drug reaction terms. J Biomed Inform 2014; 49: 282-291, https://doi.org/10.1016/j.jbi.2014.03.012.

42. Luo Y., Szolovits P. Efficient queries of stand-off annotations for natural language processing on electronic medical records. Biomed Inform Insights 2016; 8: 29-38, https://doi.org/10.4137/bii.s38916.

43. McInnes B.T., Stevenson M. Determining the difficulty of Word Sense Disambiguation. J Biomed Inform 2014; 47: 8390, https://doi.org/10.1016/j.jbi.2013.09.009.

44. Skrøvseth S.O., Augestad K.M., Ebadollahi S. Datadriven approach for assessing utility of medical tests using electronic medical records. J Biomed Inform 2015; 53: 270276, https://doi.org/10.1016/j.jbi.2014.11.011.

45. Skeppstedt M., Kvist M., Nilsson G.H., Dalianis H.
Automatic recognition of disorders, findings, pharmaceuticals and body structures from clinical text: an annotation and machine learning study. J Biomed Inform 2014; 49: 148-158, https://doi.org/10.1016/j.jbi.2014.01.012.

46. Tang B., Wu Y., Jiang M., Chen Y., Denny J.C., Xu H. A hybrid system for temporal information extraction from clinical text. J Am Med Inform Assoc 2013; 20(5): 828-835, https://doi.org/10.1136/amiajnl-2013-001635.

47. El Emam K., Farah H., Samet S., Essex A., Jonker E., Kantarcioglu M., Earle C.C. A privacy preserving protocol for tracking participants in phase I clinical trials. J Biomed Inform 2015; 57: 145-162, https://doi.org/10.1016/j.jbi.2015. 06.019 .

48. Rajamani S., Chen E.S., Akre M.E., Wang Y., Melton G.B. Assessing the adequacy of the HL7/ LOINC Document Ontology Role axis. J Am Med Inform Assoc 2015; 22(3): 615-620, https://doi.org/10.1136/ amiajnl-2014-003100.

49. Krist A.H., Woolf S.H., Bello G.A., Sabo R.T., Longo D.R., Kashiri P., Etz R.S., Loomis J., Rothemich S.F., Peele J.E., Cohn J. Engaging primary care patients to use a patient-centered personal health record. Ann Fam Med 2014; 5: 418-426, https://doi.org/10.1370/afm.1691.

50. Leaman R., Khare R., Lu Z. Challenges in clinical natural language processing for automated disorder normalization. J Biomed Inform 2015; 57: 28-37, https://doi. org/10.1016/j.jbi.2015.07.010.

51. Skałkowski K., Zieliński K. Applying formalized rules for treatment procedures to data delivered by personal medical devices. J Biomed Inform 2013; 46(3): 530-540, https://doi. org/10.1016/j.jbi.2013.04.005.

52. Kim S., Liu H., Yeganova L., Wilbur W.J. Extracting drug-drug interactions from literature using a rich featurebased linear kernel approach. J Biomed Inform 2015; 55: 23 30, https://doi.org/10.1016/j.jbi.2015.03.002.

53. McCoy A.B., Wright A., Rogith D., Fathiamini S., Ottenbacher A.J., Sittig D.F. Development of a clinician reputation metric to identify appropriate problem-medication pairs in a crowdsourced knowledge base. J Biomed Inform 2014; 48: 66-72, https://doi.org/10.1016/j.jbi.2013.11.010.

54. Deutsch E.W., Albar J.P., Binz P.A., Eisenacher M., Jones A.R., Mayer G., Omenn G.S., Orchard S., Vizcaíno J.A., Hermjakob $\mathrm{H}$. Development of data representation standards by the human proteome organization proteomics standards initiative. J Am Med Inform Assoc 2015; 22(3): 496-506, https://doi.org/10.1093/jamia/ocv001.

55. Lopetegui M., Yen P.-Y., Lai A., Jeffries J., Embi P., Payne P. Time motion studies in healthcare: what are we talking about? J Biomed Inform 2014; 49: 292-299, https://doi. org/10.1016/j.jbi.2014.02.017.

56. Vincent C.J., Blandford A. Usability standards meet scenario-based design: challenges and opportunities. J Biomed Inform 2015; 53: 243-250, https://doi.org/10.1016/j. jbi.2014.11.008.

57. Wijdicks EF. Brain death worldwide: accepted fact but no global consensus in diagnostic criteria. Neurology 2002; 58(1): 20-25, https://doi.org/10.1212/wnl.58.1.20.

58. Khare R., Li J., Lu Z. Labeledln: cataloging labeled indications for human drugs. J Biomed Inform 2014; 52: 448456, https://doi.org/10.1016/j.jbi.2014.08.004.

59. Ochs C., Geller J., Perl Y., Chen Y., Xu J., Min H., Case J.T., Wei Z. Scalable quality assurance for large SNOMED CT hierarchies using subject-based subtaxonomies. 
J Am Med Inform Assoc 2015; 22: 507-518, https://doi. org/10.1136/amiajnl-2014-003151.

60. Luo L., Mejino J.L.V. Jr., Zhang G.-Q. An analysis of FMA using structural self-bisimilarity. J Biomed Inform 2013; 46(3): 497-505, https://doi.org/10.1016/j.jbi.2013.03.005.

61. Mamykina L., Smaldone A.M., Bakken S.R. Adopting the sensemaking perspective for chronic disease selfmanagement. J Biomed Inform 2015; 56: 406-417, https://doi. org/10.1016/j.jbi.2015.06.006.

62. Gobbel G.T., Reeves R., Jayaramaraja S., Giuse D., Speroff T., Brown S.H., Elkin P.L., Matheny M.E. Development and evaluation of RapTAT: a machine learning system for concept mapping of phrases from medical narratives. J Biomed Inform 2014; 48: 54-65, https://doi.org/10.1016/j. jbi.2013.11.008.

63. Yabroff K.R., Francisci S., Mariotto A., Mezzetti M., Gigli A., Lipscomb J. Advancing comparative studies of patterns of care and economic outcomes in cancer: challenges and opportunities. J Natl Cancer Inst Monogr 2013; 46: 1-6, https://doi.org/10.1093/jncimonographs/lgt005.

64. South B.R., Mowery D., Suo Y., Leng J., Ferrández Ó., Meystre S.M., Chapman W.W. Evaluating the effects of machine pre-annotation and an interactive annotation interface on manual de-identification of clinical text. J Biomed Inform 2014; 50: 162-172, https://doi.org/10.1016/j.jbi.2014. 05.002 .

65. Sarker A., Gonzalez G. Portable automatic text classification for adverse drug reaction detection via multicorpus training. J Biomed Inform 2015; 53: 196-207, https:// doi.org/10.1016/j.jbi.2014.11.002.

66. Xierali I.M., Hsiao C.J., Puffer J.C., Green L.A., Rinaldo J.C., Bazemore A.W., Burke M.T., Phillips R.L. Jr. The rise of electronic health record adoption among family physicians. Ann Fam Med 2013; 11(1): 14-19, https://doi. org/10.1370/afm.1461.

67. Sarker A., Ginn R., Nikfarjam A., O'Connor K., Smith K., Jayaraman S., Upadhaya T., Gonzalez G. Utilizing social media data for pharmacovigilance: a review. J Biomed Inform 2015; 54: 202-212, https://doi.org/10.1016/j. jbi.2015.02.004.

68. Chow M., Beene M., O'Brien A., Greim P., Cromwell T., DuLong D., Bedecarre D. A nursing information model process for interoperability. J Am Med Inform Assoc 2015; 22(3): 608614, https://doi.org/10.1093/jamia/ocu026.

69. Viana-Ferreira C., Ribeiro L.S., Costa C. A framework for integration of heterogeneous medical imaging networks. Open Med Inform J 2014; 8(1): 20-32, https://doi.org/10.2174/ 1874431101408010020.

70. Kaggal V.C., Elayavilli R.K., Mehrabi S., Pankratz J.J., Sohn S., Wang Y., Li D., Rastegar M.M., Murphy S.P., Ross J.L., Chaudhry R., Buntrock J.D., Liu H. Toward a Learning Health-care System - knowledge delivery at the point of care empowered by big data and NLP. Biomed Inform Insights 2016; 8(1): 13-22, https://doi.org/10.4137/bii. s37977.

71. GOST $R$ ISO/TO 20514-2009. Health informatics. Electronic health record. Definition, scope and context. URL: http://docs.cntd.ru/document/gost-r-iso-to-20514-2009.

72. Kartashova A.L. The case history as the basic legal document. Sovremennye tendentsii razvitiya nauki $i$ tekhnologiy 2016; 5-1: 108-113.

73. Gagnon M.P., Ghandour el K., Talla P.K., Simonyan D., Godin G., Labrecque M., Ouimet M., Rousseau M. Electronic health record acceptance by physicians: testing an integrated theoretical model. J Biomed Inform 2014; 48: 17-27, https:// doi.org/10.1016/j.jbi.2013.10.010.

74. Harris M.R., Langford L.H., Miller H., Hook M., Dykes P.C., Matney S.A. Harmonizing and extending standards from a domain-specific and bottom-up approach: an example from development through use in clinical applications. J Am Med Inform Assoc 2015; 22(3): 545-552, https://doi. org/10.1093/jamia/ocu020.

75. Hripcsak G., Albers D.J. Correlating electronic health record concepts with healthcare process events. J Am Med Inform Assoc 2013; 20(e2): e311-e318, https://doi.org/10.1136/ amiajnl-2013-001922.

76. Hripcsak G., Albers D.J. Next-generation phenotyping of electronic health records. J Am Med Inform Assoc 2013; 20(1): 117-121, https://doi.org/10.1136/amiajnl-2012-001145.

77. Hripcsak G., Albers D.J., Perotte A. Parameterizing time in electronic health record studies. J Am Med Inform Assoc 2015; 22(4): 794-804, https://doi.org/10.1093/jamia/ ocu051.

78. Kamdar M.R., Zeginis D., Hasnain A., Decker S., Deus H.F. ReVeaLD: a user-driven domain-specific interactive search platform for biomedical research. J Biomed Inform 2014; 47: 112-130, https://doi.org/10.1016/j. jbi.2013.10.001.

79. Hanauer D.A., Mei Q., Law J., Khanna R., Zheng K. Supporting information retrieval from electronic health records: a report of University of Michigan's nine-year experience in developing and using the Electronic Medical Record Search Engine (EMERSE). J Biomed Inform 2015; 55: 290-300, https://doi.org/10.1016/j.jbi.2015.05.003.

80. Legaz-García M. del C., Menárguez-Tortosa M., Fernández-Breis J.T., Chute C.G., Tao C. Transformation of standardized clinical models based on OWL technologies: from CEM to OpenEHR archetypes. J Am Med Inform Assoc 2015; 22(3): 536-544, https://doi.org/10.1093/jamia/ocu027.

81. Marcos C., González-Ferrer A., Peleg M., Cavero C. Solving the interoperability challenge of a distributed complex patient guidance system: a data integrator based on HL7's Virtual Medical Record standard. J Am Med Inform Assoc 2015; 22: 587-599, https://doi.org/10.1093/jamia/ocv003.

82. GOST R 52636-2006. Electronic health record. URL: http://docs.cntd.ru/document/1200048924.

83. Federal Law No.258-FZ "On amending certain legislative acts of the Russian Federation and invalidating certain provisions of legislative acts of the Russian Federation on licensing of certain types of activity" dated 08.11.2007. URL: http://www.consultant.ru/document/cons_ doc_LAW_72387.

84. Fe deral Law No.1-FZ "On electronic digital signature" dated 10.01.2002. URL: http://www.consultant.ru/document/ cons doc LAW 34838.

85. Clancy T.R., Bowles K.H., Gelinas L., Androwich I., Delaney C., Matney S., Sensmeier J., Warren J., Welton J., Westra B. A call to action: engage in big data science. Nursing Outlook 2014; 62(1): 64-65, https://doi.org/10.1016/j. outlook.2013.12.006.

86. Chen Y., Carroll R.J., Hinz E.R., Shah A., Eyler A.E., Denny J.C., Xu H. Applying active learning to high-throughput phenotyping algorithms for electronic health records data. J Am Med Inform Assoc 2013; 20(e2): e253-e259, https://doi. org/10.1136/amiajnl-2013-001945.

87. Ancker J.S., Kern L.M., Edwards A., Nosal S., 
Stein D.M., Hauser D., Kaushal R. Associations between healthcare quality and use of electronic health record functions in ambulatory care. J Am Med Inform Assoc 2015; 22(4): 864871, https://doi.org/10.1093/jamia/ocv030.

88. Cimino J.J., Frisse M.E., Halamka J., Sweeney L., Yasnoff W. Consumer-mediated health information exchanges: the 2012 ACMI debate. J Biomed Inform 2014; 48: 5-15, https://doi.org/10.1016/j.jbi.2014.02.009.

89. Chen Z., Wang Z., Wang H., Owonikoko T.K., Kowalski J., Khuri F.R. Interactive software "Isotonic Design using Normalized Equivalent Toxicity Score (IDNETS(CTM)" for cancer phase I clinical trials. Open Med Informat J 2013; 7: 8-17, https://doi.org/10.2174/ 1874431101307010008.

90. Hsiao C.J., Jha A.K., King J., Patel V., Furukawa M.F., Mostashari F. Office-based physicians are responding to incentives and assistance by adopting and using electronic health records. Health Aff 2013; 32(8): 1470-1477, https://doi. org/10.1377/hlthaff.2013.0323.

91. Carroll L.N., Au A.P., Detwiler L.T., Fu T., Painter I.S., Abernethy N.F. Visualization and analytics tools for infectious disease epidemiology: a systematic review. J Biomed Inform 2014; 51: 287-298, https://doi.org/10.1016/j.jbi.2014. 04.006 .

92. Braga R.D., de Lucena F.N., Ribeiro-Rotta R.F. A multiprofessional information model for Brazilian primary care: defining a consensus model towards an interoperable electronic health record. Int J Med Inform 2016; 90: 48-57, https://doi.org/10.1016/j.jimedinf.2016.03.004.

93. Komarova K.V. Monitoring bazovykh stantsiy. $\mathrm{V} \mathrm{kn}$.: Proryvnye innovatsionnye issledovaniya [Monitoring base stations. In: Breakthrough research]. Pod red. Gulyaeva G.Yu. [Gulyaev G.Yu. (editor)]. Penza: MTSNS "Nauka i prosveshchenie"; 2016; p. 13-20.

94. Edge S.B. The challenge of quality in breast care: beyond accreditation. J Oncol Practice 2013; 9(9): 271-272, https://doi.org/10.1200/jop.2012.000792.

95. Medvedeva Y.A., Lennartsson A., Ehsani R., Kulakovskiy I.V., Vorontsov I.E., Panahandeh P., Khimulya G., Kasukawa T., Drabløs F.; FANTOM Consortium. EpiFactors: a comprehensive database of human epigenetic factors and complexes. Database 2015; 8(19): 1-10, https://doi. org/10.1093/database/bav067.

96. Bellos E., Kumar V., Lin C., Maggi J., Phua Z.Y., Cheng C.Y., Cheung C.M., Hibberd M.L., Wong T.Y., Coin L.J., Davila S. CnvCapSeq: detecting copy number variation in longrange targeted resequencing data. Nucleic Acids Res 2014; 42(20): e158, https://doi.org/10.1093/nar/gku849.

97. Hajian-Tilaki K. Sample size estimation in diagnostic test studies of biomedical informatics. J Biomed Inform 2014; 48: 193-204, https://doi.org/10.1016/j.jbi.2014.02.013.

98. Curcin V., Woodcock T., Poots A.J., Majeed A., Bell D. Model-driven approach to data collection and reporting for quality improvement. J Biomed Inform 2014; 52: 151-162, https://doi.org/10.1016/j.jbi.2014.04.014.

99. Miller R. Anesteziya [Anesthesia]. Saint Petersburg: Izdatelstvo "Chelovek"; 2015; 3328 p.

100. Zhang Y., Yu Z., Ban R., Zhang H., Iqbal F., Zhao A., Li A., Shi Q. DeAnnCNV: a tool for online detection and annotation of copy number variations from whole-exome sequencing data. Nucleic Acids Res 2015; 43(W1): W289W294, https://doi.org/10.1093/nar/gkv556.

101. Zhang R., Cairelli M.J., Fiszman M., Rosemblat G.,
Kilicoglu H., Rindflesch T.C., Pakhomov S.V., Melton G.B. Using semantic predications to uncover drug-drug interactions in clinical data. J Biomed Inform 2014; 49: 134-147, https://doi. org/10.1016/j.jbi.2014.01.004.

102. Voss E.A., Makadia R., Matcho A., Ma Q., Knoll C., Schuemie M., DeFalco F.J., Londhe A., Zhu V., Ryan P.B. Feasibility and utility of applications of the common data model to multiple, disparate observational health databases. J Am Med Inform Assoc 2015; 22(3): 553-564, https://doi. org/10.1093/jamia/ocu023.

103. Boyarinov G.A., Kuznetsov A.N., Kuznetsov A.B., Kushnikov O.I. Engineering and technical problems of anesthesiology, resuscitation and intensive care of critical conditions. Vestnik intensivnoy terapii 2016; S2: 10-12.

104. Kulinich O.V. Significance of permanent potential level in predicting critical incidents after extensive abdominal surgery in elderly patients. Vestnik intensivnoy terapii 2016; S1: 88-91.

105. Zaripova Z.A., Polushin Yu.S. Simulated critical incident in simulation training. Virtualnye tekhnologii $v$ meditsine 2015; 2(14): 8-11.

106. Kaushanskaya L.V., Lelik M.P., Dyagilev M.A., Pukhtinskaya M.V., Korneeva A.S. Training cardiopulmonary cerebral resuscitation at simulation centers. Virtualnye tekhnologii v meditsine 2016; 1(15): 20-22.

107. Rikfleks V.P., Muldaeva G.M., Klochkova E.V., Kolesnikova E.A., Shushaeva A.A. Organizing and carrying out group objective structured clinical examination. Virtualnye tekhnologii v meditsine 2016; 1(15): 35-39.

108. Cooper L., Nossaman B. Medication errors in anesthesia: a review. Int Anesthesiol Clin 2013; 51(1): 1-12, https://doi.org/10.1097/aia.0b013e31827d6486.

109. Nanji K.C., Patel A., Shaikh S., Seger D.L., Bates D.W. Evaluation of perioperative medication errors and adverse drug events. Anesthesiology 2016; 124(1): 25-34, https://doi.org/10.1097/aln.0000000000000904.

110. Fodeh S.J., Brandt C., Luong T.B., Haddad A., Schultz M., Murphy T., Krauthammer M. Complementary ensemble clustering of biomedical data. $J$ Biomed Inform 2013; 46(3): 436-443, https://doi.org/10.1016/j. jbi.2013.02.001.

111. Kumar S., Merchant S., Reynolds R. Tele-ICU: efficacy and cost-effectiveness approach of remotely managing the critical care. Open Med Inform J 2013; 7: 24-29, https://doi. org/10.2174/1874431101307010024.

112. Miller R.A. Cognitive informatics in health and biomedicine: case studies on critical care, complexity, and errors. Vimla L. Patel, David R. Kaufman, Trevor Cohen (Eds.). Springer, London (2014). 505 pages. J Biomed Inform 2014; 49: 9-10, https://doi.org/10.1016/j.jbi.2014.04.011.

113. Warner J.L., Zollanvari A., Ding Q., Zhang P., Snyder G.M., Alterovitz G. Temporal phenome analysis of a large electronic health record cohort enables identification of hospital-acquired complications. J Am Med Inform Assoc 2013; 20(e2): e281-e287, https://doi.org/10.1136/ amiajnl-2013-001861.

114. Peute L.W.P., de Keizer N.F., Jaspers M.W.M. The value of retrospective and concurrent think aloud in formative usability testing of a physician data query tool. J Biomed Inform 2015; 55: 1-10, https://doi.org/10.1016/j.jbi.2015.02.006.

115. Walker M., Hermann C.D., Williams J.K., Vidacovic B., Olivares-Navarette R., Schwartz Z., Boyan B.D. Automated analysis and predictive modeling 
of craniosynostosis with cranial suture measurements and intracranial volume asymmetries using the snake algorithm. J Biomed Eng Inform 2016; 2(2): 132-149, https://doi. org/10.5430/jbei.v2n2p132.

116. Franke S., Meixensberger J., Neumuth T. Multiperspective workflow modeling for online surgical situation models. J Biomed Inform 2015; 54: 158-166, https://doi. org/10.1016/j.jbi.2015.02.005

117. Loizou C.P., Pantziaris M. An integrated system for the complete segmentation of the common carotid artery bifurcation in ultrasound images. J Biomed Eng Inform 2015; 1(1): 11-24, https://doi.org/10.5430/jbei.v1n1p11.

118. Alexandridis A., Chondrodima E. A medical diagnostic tool based on radial basis function classifiers and evolutionary simulated annealing. J Biomed Inform 2014; 49: 61-72, https:// doi.org/10.1016/j.jbi.2014.03.008.

119. Tay D., Poh C.L., Kitney R.I. A novel neural-inspired learning algorithm with application to clinical risk prediction. J Biomed Inform 2015; 54: 305-314, https://doi.org/10.1016/j. jbi.2014.12.014.

120. Krist A.H. Electronic health record innovations for healthier patients and happier doctors. J Am Board Fam Med 2015; 28(3): 299-302, https://doi.org/10.3122/ jabfm.2015.03.150097.

121. Altini M., Casale P., Penders J., Amft O. Personalized cardiorespiratory fitness and energy expenditure estimation using hierarchical Bayesian models. J Biomed Inform 2015; 56 : 195-204, https://doi.org/10.1016/j.jbi.2015.06.008.

122. Gardeux V., Bosco A., Li J., Halonen M.J., Jackson D., Martinez F.D., Lussier A.Y. Towards a PBMC "virogram assay" for precision medicine: Concordance between ex vivo and in vivo viral infection transcriptomes. J Biomed Inform 2015; 55: 94-103, https://doi.org/10.1016/j. jbi.2015.03.003.

123. Vasilevskiy Yu.V., Simakov S.S., Gamilov T.M., Pryamonosov R.A. Personalizirovannaya vychislitelnaya otsenka fraktsionirovannogo rezerva krovotoka. V kn.: Materialy $V$ sezda biofizikov Rossii. T. 1 [Patient-specific computational assessment of fractional flow reserve. In: Materials of the 5th Congress of Russian Biophysicists. Vol. 1]. Pod red. Rubina A.B., Uzdenskogo A.B. [Rubin A.B., Uzdenskiy A.B. (editors)]. Rostov-on-Don: Izdatelstvo Yuzhnogo federalnogo universiteta; 2015; p. 14.

124. Wang S., Jiang X., Wu Y., Cui L., Cheng S., OhnoMachado L. EXpectation Propagation LOgistic REgRession (EXPLORER): Distributed privacy-preserving online model learning. J Biomed Inform 2013; 46(3): 480-496, https://doi. org/10.1016/j.jbi.2013.03.008.

125. Petrov D.A., Galeb K.E.S., Proskurin S.G. Optical coherence tomography B-scan simulation using monte carlo method with voxel geometry representation of an object. Fundamentalnye issledovaniya 2016; 5-2: 275-278.

126. Soloveva O.E. Modelirovanie miokarda: ot kletki do organa. V kn.: Materialy $V$ sezda biofizikov Rossii. T. 1 [Myocardial modeling: from cell to organ. In: Materials of the 5th Congress of Russian Biophysicists. Vol. 1]. Pod red. Rubina A.B., Uzdenskogo A.B. [Rubin A.B., Uzdenskiy A.B. (editors)]. Rostov-on-Don: Izdatelstvo Yuzhnogo federalnogo universiteta; 2015; p. 48.

127. Ayvaz S., Horn J., Hassanzadeh O., Zhu Q., Stan J., Tatonetti N.P., Vilar S., Brochhausen M., Samwald M., Rastegar-Mojarad M., Dumontier M., Boyce R.D. Toward a complete dataset of drug-drug interaction information from publicly available sources. J Biomed Inform 2015; 55: 206217, https://doi.org/10.1016/j.jbi.2015.04.006.

128. Chen Y., Ghosh J., Bejan C.A., Gunter C.A., Gupta S., Kho A., Liebovitz D., Sun J., Denny J., Malin B. Building bridges across electronic health record systems through inferred phenotypic topics. J Biomed Inform 2015; 55: 82-93, https://doi.org/10.1016/j.jbi.2015.03.011.

129. Liu B., Madduri R.K., Sotomayor B., Chard K., Lacinski L., Dave U.J., Li J., Liu C., Foster I.T. Cloudbased bioinformatics workflow platform for large-scale nextgeneration sequencing analyses. J Biomed Inform 2014; 49: 119-133, https://doi.org/10.1016/j.jbi.2014.01.005.

130. Fricke W.F., Rasko D.A. Bacterial genome sequencing in the clinic: bioinformatic challenges and solutions. Nat Rev Genet 2014; 15(1): 49-55, https://doi. org/10.1038/nrg3624.

131. Gotz D., Wang F., Perer A. A methodology for interactive mining and visual analysis of clinical event patterns using electronic health record data. J Biomed Inform 2014; 48: 148-159, https://doi.org/10.1016/j.jbi.2014.01.007.

132. Kakouros N. Distributed storage healthcare - the basis of a planet-wide public health care network. Open Med Inform J 2013; 7: 1-7, https://doi.org/10.2174/1874431101307 010001.

133. Klann J.G., Buck M.D., Brown J., Hadley M., Elmore R., Weber G.M., Murphy S.N. Query Health: standardsbased, cross-platform population health surveillance. J Am Med Inform Assoc 2014; 21(4): 650-656, https://doi. org/10.1136/amiajnl-2014-002707.

134. Le T., Chaudhuri S., Chung J., Thompson H.J., Demiris G. Tree testing of hierarchical menu structures for health applications. J Biomed Inform 2014; 49: 198-205, https://doi.org/10.1016/j.jbi.2014.02.011.

135. Guidance for industry and food and drug administration staff. 2016. URL: https://www.fda.gov/ downloads/medicaldevices/deviceregulationandguidance/ guidancedocuments/ucm482022.pdf.

136. Pokhilenko O.V. Secure way to share and store data using cloud storage. Sovremennye tendentsii razvitiya nauki $i$ tekhnologiy 2016; 6-1: 78-83.

137. Ponomareva N.S., Panich A.E. Ekspertnaya sistema podderzhki prinyatiya resheniy $\mathrm{v}$ otsenke sostoyaniya reproduktivnoy sistemy cheloveka. $\mathrm{V}$ kn.: Materialy $\mathrm{V}$ sezda biofizikov Rossii. T. 2 [Expert decision-support system in assessing the state of human reproductive system. In: Materials of the 5th Congress of Russian Biophysicists. Vol. 2]. Pod red. Rubina A.B., Uzdenskogo A.B. [Rubin A.B., Uzdenskiy A.B. (editors)]. Rostov-on-Don: Izdatelstvo Yuzhnogo federalnogo universiteta; 2015; p. 24.

138. Westra B.L., Latimer G.E., Matney S.A., Park J.I., Sensmeier J., Simpson R.L., Swanson M.J., Warren J.J., Delaney C.W. A national action plan for sharable and comparable nursing data to support practice and translational research for transforming health care. J Am Med Inform Assoc 2015; 22(3): 600-607, https://doi.org/10.1093/jamia/ ocu011.

139. Luo J., Wu M., Zhao Y. Big data application in biomedical research and health care: a literature review. Biomed Inform Insights 2016; 8: 1-10, https://doi.org/10.4137/ bii.s31559.

140. Klann G., Szolovits P., Downs S.M., Schadow G. Decision support from local data: creating adaptive order menus from past clinician behavior. J Biomed Inform 


\section{REVIEWS}

2014; 48: 84-93, https://doi.org/10.1016/j.jbi.2013.12.005. 141. Shin D., Arthur G., Popescu M., Korkin D., Shyu C.-R. Uncovering influence links in molecular knowledge networks to streamline personalized medicine. J Biomed Inform 2014; 52 : 394-405, https://doi.org/10.1016/j.jbi.2014.08.003.

142. Smolyar O.V. A method for calculating the required performance of local area network. Sovremennye tendentsii razvitiya nauki i tekhnologiy 2016; 6-1: 89-91.
143. Shyr C., Kushniruk A., Wasserman W.W. Usability study of clinical exome analysis software: top lessons learned and recommendations. J Biomed Inform 2014; 51: 129-136, https://doi.org/10.1016/j.jbi.2014.05.004.

144. Kuznetsov A.B., Shchegolkov L.A. Prognozirovanie rezultatov lecheniya patsienta $v$ kriticheskom sostoyanii [Predicting the results of treatment of a patient in a critical condition]. Nizhny Novgorod: Izdatelstvo NizhGMA; 2017. 